\title{
GENOMICS, BIOTECHNOLOGY AND GLOBAL HEALTH: THE WORK OF THE UNIVERSITY OF TORONTO JOINT CENTRE FOR BIOETHICS
}

\author{
Abdallah S. Daar ${ }^{*}$ Puja Sahni* ${ }^{* *}$ and Peter A. Singer ${ }^{* * *}$
}

\begin{abstract}
The new and rapidly advancing field of genomics and related biotechnologies has the ability to either improve or worsen global health inequities. In general, developing countries are left behind in the development of new technologies and advances in genomic medicine.

In this view, the University of Toronto Joint Centre for Bioethics (JCB) through the Canadian Program on Genomics and Global Health has developed 25 research projects on capacity enhancement for developing countries for improving global health equity, including public health via genomics and related biotechnologies. One project with a great impact was the "Top Ten Biotechnologies for Improving Health in Developing Countries" for its influence in the "Grand Challenges in Global Health Initiative" foster by the Melinda Gates Foundation.

Additionally, the UN Millennium Development Project has asked JCB to become the genomics working group for improving global health through genomics biotechnology and JCB has started by studying applications of genomics/biotechnologies in seven developing countries: Brazil, China, Cuba, Egypt, India, South Africa and South Korea, which may set examples for other developing nations.
\end{abstract}

Key words: Genomics, biotechnology, global health equity

\section{GENÓMICA, BIOTECNOLOGÍA Y SALUD MUNDIAL: EL TRABAJO DEL CENTRO ASOCIADO DE BIOÉTICA DE LA UNIVERSIDAD DE TORONTO}

Resumen: El nuevo campo de la genómica y sus biotecnologías relacionadas, de rápido desarrollo, tiene la habilidad tanto de mejorar como de empeorar las desigualdades globales en salud. En general, los países en desarrollo quedan atrás en el desarrollo de nuevas tecnologías y avances en la medicina genómica.

En vista de esta situación, el Centro Asociado de Bioética de la Universidad de Toronto (JCB) a través del Programa Canadiense sobre Genómica y Salud Global ha desarrollado 25 proyectos de investigación sobre desarrollo de capacidades en países en desarrollo para mejorar la equidad en salud global, incluyendo la salud pública a través de la genómica y sus biotecnologías relacionadas. Entre estos, un proyecto de gran impacto fue "Diez Biotecnologías de Mayor Importancia para Mejorar la Salud en Países en Desarrollo" por su influencia en la "Iniciativa sobre los Grandes Desafíos en Salud Global” presentada por la Fundación Bill and Melinda Gates.

Además, el proyecto de las Naciones Unidas "Desarrollos del Milenio" pidió a JCB ser el grupo de trabajo de genómica para la mejora de la salud global a través de la biotecnología genómica, y JCB ha comenzado estudiando aplicaciones de genómica y biotecnología en siete países en desarrollo: Brasil, China, Cuba, Egipto, India, Sudáfrica y Sur Corea, que pueden servir de ejemplo para otras naciones en desarrollo.

Palabras clave: Genómica, biotecnología, equidad en salud global

\section{GENÓMICA, BIOTECNOLOGIA E SAÚDE MUNDIAL: O TRABALHO DO CENTRO ASSOCIADO DE BIOÉTICA DA UNIVERSIDADE DE TORONTO}

Resumo: O novo campo da genómica e suas biotecnologías relacionadas, de rápido desenvolvimento, tem a habilidade tanto de melhorar como de piorar as desigualdades globais em saúde. Em geral, os países em desenvolvimento ficam atrás no desenvolvimento de novas tecnologias e avanços na medicina genómica. Em vista desta situação, o Centro Associado de Bioética da Universidade de Toronto (JCB) através do Programa Canadense sobre Genómica e Saúde Global desenvolveu 25 projetos de pesquisa sobre desenvolvimento de capacitações em países em desenvolvimento para melhorar a equidade em saúde global, incluindo a saúde pública através da genómica e suas biotecnologias relacionadas. Entre estes, um projeto de grande impacto foi "Dez Biotecnologías Mais Importantes para Melhorar a Saúde em Países em Desenvolvimento" por sua influência na "Iniciativa sobre os Grandes Desafios em Saúde Global" apresentada pela Fundação Bill and Melinda Gates. Alem disso, o projeto das Nações Unidas "Desenvolvimentos do Milênio" pediu para que o JCB fosse o grupo de trabalho de genómica para a melhora da saúde global através da biotecnologia genómica, e o JCB começou estudando aplicações de genómica e biotecnologia em sete países em desenvolvimento: Brasil, China, Egito, Índia, África do Sul e Coréia do Sul, que podem servir de exemplo para outra nações em desenvolvimento.

Palavras-chave: Genómica, biotecnologia, equidade em saúde global

* University of Toronto Joint Centre for Bioethics

Correspondencia: a.daar@utoronto.ca 


\section{Introduction}

The year 2003 welcomed the achievement of two major milestones in genomics. First, it marked the $50^{\text {th }}$ anniversary of Watson and Crick's discovery of DNA, and second, the completion of the human genome project. How can all of mankind benefit from these epochal advances?

In his remarks at the School of Public Health Leadership Council inaugural meeting, Harvard University President Larry Summers highlighted the two most important issues facing mankind today: first is the health of people in the developing world, particularly those in Africa; second is the emerging revolution in the life sciences which, for the first time, is providing us with a fundamental understanding of human nature ${ }^{1}$.

The University of Toronto Joint Centre for Bioethics (JCB) has chosen to focus its research program on addressing these two very issues through its Canadian Program on Genomics and Global Health (CPGGH). This is because we believe that global health inequity is one of the most important ethical issues facing the world today. It is evident in the large differences between life expectancy figures for industrialized and developing countries. Life expectancy in Canada is 80 years and rising; in sub-Saharan Africa, it is 40 years and falling. Inequities exist in the number of deaths due to preventable diseases - a figure much higher in the developing world than in the industrialized west. There is also a 10//90 gap: only $10 \%$ of public and private health research expenditure is devoted to the health issues affecting $90 \%$ of the global population ${ }^{2}$. Most genomics research

Summers L. "Remarks of President Lawrence H. Summers, School of Public Health Leadership Council Inaugural Meeting." Cambridge, Massachusetts. October 21, 2003.

Global Forum for Health Research. The 10/90 Report on Health Research 2003-2004. Global Forum for Health Research; 2004. also focuses on health issues affecting the wealthiest countries in the world(1).

The new and rapidly advancing field of genomics and related biotechnologies has the ability to either improve or worsen such disparities. New technologies and advances in medicine continue to develop, yet developing countries continue to be left behind.

In light of this knowledge we were concerned that, like the information technology and agricultural biotechnology waves, the benefits of genomics might not be realized in developing countries. The potential for such a "genomics divide" has led us to develop and propose a strategy for systematically harnessing genomics to benefit health in the developing world. ${ }^{3}$ We have developed a number of research and capacity enhancement projects under the umbrella of CPGGH. The program now has 25 such projects, each designed to pursue specific goals and objectives with the ultimate aim of averting a genomics divide and improving global health equity (Table 1).

Genomics traditionally refers to the study of all the genes in a person or organism. However we found this definition to be operationally inadequate for our research, and have developed our own definition of genomics to be the "powerful new wave of health related life sciences (biotechnologies) energized by the human genome project and the knowledge and tools it is spawning (i.e. proteomics, transcriptomics, metabolomics, etc.) ${ }^{\prime \prime 3}$.

In this paper we highlight a small number of the major CPGGH projects. The projects on the whole aim at improving global health equity, including public health, via genomics and

University of Toronto Joint Centre for Bioethics. Top 10 biotechnologies for improving health in developing countries. 2002. [Website] Available at http://www.utoronto.ca/jcb/ home/news_genomics.htm 
related biotechnologies. A complete list of program goals, objectives and projects is available at the CPGGH website ${ }^{4}$.

\section{Top 10 Biotechnologies for Improving Health in Developing Countries}

Of the various projects conducted through the CPGGH to date, the Top 10 Biotechnologies for Improving Health in Developing Countries has so far had the greatest global impact. The project was initiated in response to a report released by the World Health Organization (WHO) in April 2002 titled, Genomics and World Health(2). The WHO report highlighted the importance of genomics for improving health in developing countries and, noting the uncertainty surrounding genomics, suggested that regular assessments of the relative potential of these technologies be conducted. These assessments would then provide researchers, funding agencies and governments in developing countries with useful information to shape policy. The Top 10 Biotechnologies study is the first to provide this valuable information. The report is targeted at policy makers, politicians, educated laypersons and others who are likely to influence policy and investment decisions in the health and biotechnology sectors.

To identify the ten most promising biotechnologies, a consensus forming exercise was conducted as part of a foresight exercise. Foresight exercises have been found to encourage innovation by increasing communication, encouraging long-term thinking, fostering better coordination between stakeholders and developing a shared future vision and commitment to specific goals. In this study, technologies were identified and ranked by an international group of 28 eminent scientists with expertise

Canadian Program in Genomics and Global Health. 2004. [Website] Available at: www.geneticsethics.net in biotechnology and global health issues. Members of this panel were identified through recommendations of individuals at the World Health Organization and the Rockefeller Foundation, as well as through literature searches. Each member was someone well acquainted with the public health issues of developing countries. Panelists were encouraged to take a broad approach in making their suggestions and to include any biotechnologies, including genomics, which would be relevant to addressing the health problems of the developing world. Suggestions could include predictive, preventative, diagnostic and therapeutic technologies, as well as those convergent between health and agricultural biotechnology.

To achieve consensus amongst the experts, the Delphi method was utilized. This structured process divided the study into three rounds via emails, faxes, phone calls and personal interviews over the span of five months. In the first round, Panelists were asked the question, "What do you think are the major biotechnologies that can help improve health in developing countries in the next five to ten years?" Each panelist was asked for his or her top three personal choices and subsequent rounds were used to establish consensus among their responses. Specific criteria were not outlined upon initial presentation of the question in round one; however, as they responded, panelists were asked to indicate the criteria upon which their choices were based. These criteria are briefly outlined in Table 2 . The top 10 biotechnologies (Table 3) are a result of this structured Delphi methodology and some of the ten will be discussed briefly below.

\section{Molecular Diagnostics}

Infectious diseases are widespread and are accountable for almost half of all deaths that occur in developing countries. The diagnostic tools currently used are often cumbersome, 
expensive and time consuming, and are therefore unsuitable for use in developing countries. Consequently, the Panel ranked "molecular technologies for affordable, simple diagnostics of infectious diseases" as the most promising biotechnology for improving health in the developing world. Presently, polymerase chain reaction tests, monoclonal antibodies and recombinant antigens are in use or are being tested in developing countries(3). These tools have proven to be very accurate and rapid in their detection of pathogen-associated molecules and can be modified for use in low-income settings. As the use of these technologies increases, and as developing countries begin manufacturing them, their affordability will increase.

\section{Recombinant Vaccines}

Almost half of all deaths in the developing world are the result of infection due to diseases such as HIV/AIDS, malaria and tuberculosis. The Panel therefore recognized the need for effective vaccines as an approach to preventative medicine and ranked recombinant vaccines second on the list. Recombinant vaccines, specifically, refer to the broad category of vaccines made via DNA manipulation. A recent study in the Gambia using a malaria subunit vaccine was shown to protect $71 \%$ of adult men against natural infection(4). Recombinant technology provides researchers with greater control over vaccine characteristics and allows for the production of safer, more effective, and possibly even less expensive vaccines. Some recombinant vaccines are already being manufactured in developing countries, often at a lower cost than the standard imported alternative. This technology also introduces the potential for developing protection against diseases for which vaccines do not yet exist.

\section{Bioremediation}

Bioremediation refers to the use of bacteria or plants to decontaminate the environment.
Human activity, such as overcrowding, rapid industrialization and inadequate sanitation, has contaminated soil, air and water, introducing major health threats to people in developing countries. Because of these concerns, the fourth biotechnology ranked by the Panel is "technologies for environmental improvement", such as bioremediation. At present, the two main types of pollution threatening human health are organic waste and heavy metals, both of which can be detoxified by bacteria. Phytoremediation, the use of plants to clean up the environment, is one way in which this technology can be implemented. Plants have the ability to degrade organic pollutants and may be considered superior to bacteria not only aesthetically but functionally, as they have the ability to store significantly large concentrations of toxic metals in their tissues.

One of the greatest mass poisonings in history is that being experienced by Bangladesh from extensive groundwater arsenic contamination. Between 35 and 77 million people in the country are at risk and at least 100000 cases of debilitating skin lesions are believed to have already occurred. Recently, a bacterium named NT-26 was discovered in an Australian gold mine. This bacterium has the natural ability to transform arsenite, a soluble form of arsenic, into arsenate which is much less toxic(5). We are leading a coalition with Canadian, Australian, Bangladeshi and American scientists to sequence and study the bacterial genomes of bacterium that both convert insoluble arsenic from the walls of aquifers into soluble arsenic in water (the cause of the problem) and those that do the opposite.

\section{Sequencing Pathogen Genomes}

The fifth on the list of biotechnologies was genome sequencing, particularly that of human pathogens. Using the same technology employed for the Human Genome Project, 
researchers can sequence the genomics of pathonogenic microorganisms. Genome sequence data, most of which is available online, can be used to develop new vaccines and drugs. This information can provide leads for drug or vaccine development. A group of Italian researchers discovered numerous vaccine candidate molecules for a particularly virulent strain of meningitis using basic bioinformatics techniques(6). This is just one of the many examples demonstrating how genome sequencing can lead to advances in vaccine development.

\section{Female-Controlled Protection against Sexually Transmitted Infections (STIs)}

The growing global burden of STIs is especially devastating to women, who have little control over safe sex methods such as use of condoms. There is thus a need for STI protection for women that is not dependent on their partner's consent. Efforts presently underway include the development of recombinant vaccines, monoclonal antibodies and new approaches to the development of vaginal microbicides. Currently, there is no safe and effective vaginal microbicide available to women. However certain research centres are working towards such a development. March 2004 marked the beginning of large-scale efficacy trials for a carrageenan-based product, the Population Council's leading microbicide. These trials come in response to results collected from several Phase I safety and acceptability trials that have shown the product to be well-tolerated in HIV-negative women from six different countries. Results from Phase I trials conducted on HIV-negative couples from Thailand show that the product is also safe for men. Several characteristics of carrageenan, such as its ability to remain stable under severe conditions, increase the suitability of the microbicide product for use in rural areas with limited infrastructure. Along with the efficacy trials underway, Phase I trials on HIV-positive women and men have also begun(7).

\section{Nutritionally Enriched Genetically Modified (GM) Crops}

With the global population expected to grow substantially over the next 45 years $^{5}$ and with limited global arable land available for cultivation $^{6}$, GM crops offer a potential solution to the expected increase in demand for healthy food. Malnutrition already affects one in five people living in developing countries and leads to increased disease susceptibility, impaired cognitive and physical development, and multiple illnesses attributed to specific nutrient deficiencies. In addressing this issue, the Panel ranked the use of genetically modified, nutrient enhanced crops as the eighth most promising biotechnology. The underlying cause of nutrient deficiency in the developing world is a diet based primarily on nutrient-poor, staple foods such as rice, potatoes, corn and cassava. To counter this problem, several enriched crops have been developed to date and are under evaluation. An example is Golden Rice, a strain of rice genetically engineered to contain increased levels of provitamin A (ß-kerotene) and iron(8). A large percentage of the global population depends on rice as a major food staple making vitamin A deficiency the leading cause of childhood blindness and suppressed immune systems in children of the developing world ${ }^{7}$. Genetically

Population Division of the Department of Economic and Social Affairs of the United Nations Secretariat. World Population Prospects: The 2002 Revision. [Website] Available at: http://esa.un.org/unpp Accessed July 23, 2004. Population Action International. Conserving land: population and sustainable food production. 1995. [Website] Available at: http://www.cnie.org/pop/conserving/expanded.htm Accessed July 19, 2004.

World Health Organization. Combating Vitamin A deficiency. 2003. [Website] Available at: http://www.who.int/ nut/vad.htm Accessed June 29, 2004. 
modified crops theoretically could offer a better solution than current interventions.

Despite the potential benefits that GM crops suggest, they require careful safety assessments prior to being released into the environment. Several criticisms have been raised against the use of GM crops with regards to the dangers they may pose to the environment and to our bodies, and that their benefits have been overestimated. However, researchers may not be limited to genetic engineering to achieve certain traits in crops. Increased knowledge in plant genomics over the past decade reveals that several plants have desired, yet dormant, characteristics and it is often possible to activate these innate abilities. Through precision/smart breeding that allows researchers to pinpoint the genes responsible for a given trait and then make use of traditional breeding techniques such as crossbreeding and tissue culturing to produce these enhanced plants without any transgenesis. Early-stage breeding is mainly done in the laboratory which saves time and money that would otherwise be spent growing several generations of plants in a field ${ }^{8}$.

Ultimately, the top 10 technologies are intended to provide researchers, funding agencies and government bodies with insight into which genomics-based technologies will likely bring improved health in the next five to ten years. Along with providing this sense of direction, the study illustrates the relevance of the genomics revolution for global health improvement. The technologies identified by the Panel are highly relevant to many of the major health problems in the developing world and have the potential to be affordable alternatives to existing methods of disease prevention, diagnosis and therapy.

Manning R. Super Organics. Wired Magazine May 2004 Issue 12.05. [Website] Available at: http://www.wired.com/ wired/archive/12.05/food.html Accessed June 18, 2004.

\section{Grand Challenges in Global Health}

One of the impacts of the top 10 biotechnologies report was an invitation from the Bill and Melinda Gates Foundation (BMGF) inviting the JCB to provide methodological support for the Grand Challenges in Global Health(9) initiative. In January 2003, the BMGF announced this $\$ 200$ million medical research initiative with the assumption that, with greater encouragement and funding, researchers would focus on health problems in the developing world. A Grand Challenge was defined as "A scientific or technological innovation that would remove a critical barrier to solving an important health problem in the developing world with a high likelihood of global impact and feasibility". An advertising campaign was launched in May of 2003 eliciting ideas for Grand Challenges from scientists around the world. Several submissions were received and final decisions were ultimately achieved by oral consensus at a scientific board meeting. The resulting challenges (Table 4) were then grouped according to seven-long range goals, none of which specifically addresses a single disease.

\section{UN Millennium Development Goals (UN MDGs)}

As part of its commitment to promote sustained development and to eliminate global poverty, the United Nations (UN) is dedicated to achieving the Millennium Development Goals (Table 5). The goals are part of a global agenda aimed at reducing poverty, hunger, disease, illiteracy, environmental degradation and discrimination against women by the year $2015^{9}$. The first seven of the eight goals are

\footnotetext{
United Nations Department of Public Information. Implementing the millennium declaration: The Millennium Development Goals and the United Nation's role. October 2002.
} 
directed at specific objectives in promoting development and improving lives, while the eighth goal focuses on developing global partnerships as a means to achieve the goals. In order to monitor the progress in achieving this commitment, a set of targets and indicators has been generated specific to each goal ${ }^{10}$.

As part of the Millennium Project, the UN has established several task forces including the Science, Technology and Innovation Task Force for which the JCB was asked to become the genomics working group. The CPGGH project, titled Harnessing Genomics and Biotechnology for the UN MDGs, examines the role of genomics and related health biotechnologies as an example of applying science, technology and innovation (STI) to meet the MDGs and improve global health. Table 6 highlights the correlation that exists between the top 10 biotechnologies and the UN MDGs and exemplifies how biotechnology can be used to provide solutions for the developing world. Despite these clear implications, these technologies are not being readily employed by developing countries. As a result, it is crucial that we work towards achieving widespread global implementation, wherever appropriate. In light of the eighth goal, "fostering a global partnership for promoting development," we have proposed a global genomics initiative that will promote genomics and biotechnology for development. The initiative proposes involvement of various sectors such as academia, government, public interest groups and the media to name a few, in order to ensure an inclusive nature that would facilitate collaborative decision making and minimize the risks associated with introducing these technologies to selected countries. This global network model encourages participation

United Nations Statistics Division. Millennium Indicators Database. 2004. [Website] Available at: http:// millenniumindicators.un.org/unsd $/ \mathrm{mi} / \mathrm{mi}$ _goals.asp Accessed July 23, 2004. by developing countries to generate nation-specific initiatives and subsequently build their capacity to address their unique health issues(10).

In order to harness the benefits of genomics for improved health care and development, the developing world needs better access to genomics knowledge. The global public goods concept(11) may assist in the transfer of this knowledge to the South. Genomics has significant characteristics as a global public good for health, as it is non-excludable and non-rival in its consumption, yet developing countries have yet to benefit from its full potential. The UN MDGs provide new opportunities for scientists to expand their research efforts in order to transfer this genomics knowledge and its applications to sustain development and reduce poverty in low-income countries.

\section{Health Biotechnology Innovation Systems}

A project currently underway at the JCB involves case studies of national health biotechnology innovation systems in seven different countries. Brazil, China, Cuba, Egypt, India, South Africa and South Korea are being studied to assess the factors that have led to the early successes in each of these countries. The results will be compared to identify the means by which these countries have integrated genomics into their approach to health and development. Based on these results, recommendations will be made for potential ways in which genomics and biotechnology can be harnessed in other developing nations.

\section{Examples of Early Applications of Genomics/Biotechnologies in Developing Countries}

Three countries that have addressed the importance of integrating genomics into their approach for health care improvements are China, 
Cuba and Mexico. While China became the first country in the world to approve the production of a gene therapy, Mexico has recognized the potential for genomics in addressing public health issues. Cuba has a vibrant health biotechnology sector that is closely linked to its health care sector. Each of these cases is further discussed below.

\section{Gene therapy in China}

China is an example of a developing country that is rapidly moving forward in the use of genomics and related biotechnologies to improve the health of its citizens. China has demonstrated this by being the first country to approve the commercial production of a gene therapy. A company called Shenzhen SiBiono GenTech obtained a drug license from the Food and Drug Administration of China for its recombinant Ad-p53 gene therapy for head and neck squamous cell carcinoma. This therapy, which was made available in 2004 under the commercial name of Genicide, offers the potential for a one-time treatment which is simple to administer. Additionally, since China is a highly populated country, it is possible to recruit enough patients to generate statistically significant results in clinical trials. Although there are criticisms against the apparent leniency of drug regulatory measures in China relative to that of the US or Europe - the fact that the gene therapy was approved in the country will likely make the technology more acceptable, and may stimulate other developing nations to follow in China's footsteps(12).

\section{Cuba and Meningitis B Vaccine Development}

Despite being a relatively small country with serious economic difficulties, Cuba has made significant advances in the field of health biotechnology. In the 1980s, Cuba was the first country, internationally, to introduce a meningitis B vaccine. This development was a prod- uct of local research projects, and came in response to a local outbreak of Meningitis B. A candidate vaccine was introduced in Cuba in 1985 and this coincided with a reduction in the incidence of this disease. One of Cuba's more recent successes is the development of the first human vaccine with a synthetic antigen. The vaccine against Haemophilus influenza type $B$ (Hib) infection, the Cuban vaccine is a much cheaper and safer product than existing vaccines. The strong commitment and involvement of government bodies, public research institutions, universities and the health system have all contributed to Cuba's progress in the health biotechnology field ${ }^{11}$.

\section{Mexico's Genomic Medicine Initiative}

In countries such as Mexico, health problems are a serious financial burden and the need for new public health measures has been recognized. Although some developing countries may decline to invest in the development of new technologies due to financial limitations, the potential for economic growth and social welfare from such an investment does exist. In 2003, Mexico launched a plan to develop a genomic medicine program which would include the establishment of an Institute of Genomics Medicine. After three years of preparation, Mexico's plans are moving towards the implementation of a National Platform for Genomics Medicine, directed by Gerardo JiménezSánchez(13). Recently, the Mexican Congress approved a law to establish the Institute of Genomics Medicine. The characteristic genetic structure of the modern Mexican population suggests that importing genomic-based technologies developed for other populations is not

\footnotetext{
11 Thorsteinsdóttir H, Daar AS, Sáenz TW, Singer PA. Building a Biopharmaceutical Innovation System in Cuba: Growth Through Linkages. In: Mytelka LK, ed. Building (bio)pharmaceutical innovation systems in developing countries. Maastricht, The Netherlands: Institute for New Technologies (INTECH), United Nations University, in press.
} 
the answer to meeting the health demands of Mexicans. Rather, the genomic applications should be geared at the genetic structures specific to Mexican people.

\section{What Can Developed Countries do to help?}

Earlier this year, the Speech from the Throne acknowledged Canada as a "knowledge-rich country" and encouraged greater application of this knowledge to help address challenges in the developing world. At present, less than 1\% of the total Canadian annual research and development budget is allocated towards targeting the health and environment problems in developing countries. In his response to the Speech from the Throne, Prime Minister Paul Martin stated that as a long-term goal, Canada should "devote no less than $5 \%$ of our research and development investment to a knowledgebased approach to develop assistance for less fortunate countries"12. The challenge is for other rich developed countries to emulate the example set by Canada.

Table 1. Canadian Program on Genomics and Global Health Projects

\section{Current Projects}

1. Top 10 Biotechnologies for Improving Health in Developing Countries

2. Genomics as a Global Public Good for Health

3. Harnessing Genomics and Biotechnology for the UN Millennium Development Goals (UNMDGs)

4. Global Genomics Initiative (GGI): Building a Public Dialogue

5. Genome Innovation Systems in Developing Countries

6. Bioscience Business Ethics

7. Ethical Guidelines for Nutrigenomics

8. Ethical Guidelines for Plant-Made Pharmaceuticals

9. Genetically Modified Animals

10. International Comparative Perspectives on Regulation of Genomics Research and on the Implications of Genetic Testing on Health Systems and Insurance

11. Regulation of Convergent Biotechnology

12. Intellectual Property Modeling Group (IPMG)

13. Regenerative Medicine

14. Regulatory Models of Genomics and Stem Cells for Developing Countries

15. Genomics and Public Health Policy Executive Course

16. Global Genomics Opinion Leaders' Network

17. Stem Cell Curricular Module for High Schools

18. Public Engagement in Genomics Through Plays

19. Nanotechnology and Development

20. Science, Technology, Innovation and Foreign Policy: Canada's Role

Upcoming Projects

21. Pharmacogenomics and Global Health

22. Biotechnology and Human Security

23. Diaspora Options: How Developing Countries Can Benefit From Their Emigrant Populations

24. Developing Country Small and Medium Enterprises

25. Next Generation Vaccines

12 University of Toronto Joint Centre for Bioethics. Energizing Canadian Foreign Policy through Science \& Technology Innovation: Vision, Benefits, and Policy Goals. 
Table 2. Criteria used by Panel for Selecting Top 10 Biotechnologies

\begin{tabular}{|c|c|}
\hline Criteria & Description \\
\hline Impact & How much difference will the technology make in improving health? \\
\hline Appropriateness & $\begin{array}{l}\text { Will it be affordable, robust and adjustable to health care settings in developing countries, } \\
\text { and will it be socially, culturally and politically acceptable? }\end{array}$ \\
\hline Burden & Will it address the most pressing health needs? \\
\hline Feasibility & Can it realistically be developed and deployed in a time frame of 5-10 years? \\
\hline Knowledge Gap & Does the technology advance health by creating new knowledge? \\
\hline Indirect Benefits & $\begin{array}{l}\text { Does it address issues such as environmental improvement and income generation that } \\
\text { have indirect, positive effects on health? }\end{array}$ \\
\hline
\end{tabular}

Table 3. Top 10 Biotechnologies for Improving Health in Developing Countries

\begin{tabular}{llc}
\hline $\begin{array}{l}\text { Final } \\
\text { Ranking }\end{array}$ & Biotechnology & $\begin{array}{c}\text { Final } \\
\text { Score }\end{array}$ \\
\hline 1 & Modified molecular technologies for affordable, simple diagnosis of infectious diseases & 288 \\
2 & Recombinant technologies to develop vaccines against infectious diseases & 262 \\
3 & Technologies for more efficient drug and vaccine delivery systems & 245 \\
4 & Technologies for environmental improvement (sanitation, clean water, bioremediation) & 193 \\
5 & Sequencing pathogen genomes to understand their biology and to identify new antimicrobials & 180 \\
6 & Female-controlled protection against sexually transmitted diseases, both with and without & \\
& contraceptive effect & 171 \\
7 & Bioinformatics to identify drug targets and to examine pathogen-host interactions & 168 \\
8 & Genetically modified crops with increased nutrients to counter specific deficiencies & 159 \\
9 & Recombinant technology to make therapeutic products (e.g. insulin, interferons) & 155 \\
10 & Combinatorial chemistry for drug discovery & 129 \\
\hline
\end{tabular}

Reference - top 10 report

Table 4. Goals and Grand Challenges

To improve childhood vaccines:

GC 1: Create effective single-dose vaccines that can be used soon after birth;

GC 2: Prepare vaccines that do not require refrigeration;

GC 3: Develop needle-free delivery systems for vaccines.

To create new vaccines:

GC 4: Devise reliable tests in model systems to evaluate live attenuated vaccines;

GC 5: Solve how to design antigens for effective, protective immunity;

GC 6: Learn which immunological responses provide protective immunity.

To control insects that transmit agents of disease:

GC 7: Develop a genetic strategy to deplete or incapacitate a disease-transmitting insect population;

GC 8: Develop a chemical strategy to deplete or incapacitate a disease-transmitting insect population.

To improve nutrition to promote health:

GC 9: Create a full range of optimal bioavailable nutrients in a single staple plant species.

To improve drug treatment of infectious diseases:

GC 10: Discover drugs and delivery systems that minimize the likelihood of drug-resistant microorganisms.

To cure latent and chronic infections:

GC 11: Create therapies that can cure latent infections;

GC 12: Create immunological methods that can cure chronic infections.

To measure disease and health status accurately and economically in poor countries:

GC 13: Develop technologies that permit quantitative assessment of population health status;

GC 14: Develop technologies that allow assessment of individuals for multiple conditions or pathogens at point-of-care. 
Table 5. United Nations Millennium Development Goals

1. Eradicate extreme poverty and hunger

2. Achieve universal primary education

3. Promote gender equality and empower women

4. Reduce child mortality

5. Improve maternal health

6. Combat HIV/AIDS, malaria and other diseases

7. Ensure environmental sustainability

8. Develop a global partnership for development

Table 6. Mapping the Top Ten Biotechnologies onto the Millennium Development Goals

\begin{tabular}{|c|c|c|c|}
\hline MDGs & Technology & Advantages & Examples \\
\hline \multirow[t]{2}{*}{$\begin{array}{l}\text { Combat } \\
\text { infectious } \\
\text { diseases } \\
\text { Reduce child } \\
\text { mortality } \\
\text { Improve maternal } \\
\text { health }\end{array}$} & $\begin{array}{l}\text { Molecular } \\
\text { diagnostics }\end{array}$ & $\begin{array}{l}\text { Early detection, timely } \\
\text { intervention } \\
\text { Helps prevent spread of infection } \\
\text { Avoids waste of resources on } \\
\text { inappropriate treatments }\end{array}$ & $\begin{array}{l}\text { Dipstick assay for the detection } \\
\text { of Salmonella typhi-specific IgM } \\
\text { antibodies. Same-day results, } \\
\text { small volume of serum needed, } \\
\text { stability of reagents and } \\
\text { simplicity of assay allow use in } \\
\text { absence of laboratory facilities. } \\
\text { (Hatta et al UN article) }\end{array}$ \\
\hline & $\begin{array}{l}\text { Recombinant } \\
\text { vaccines }\end{array}$ & $\begin{array}{l}\text { Reduced risk compared with } \\
\text { attenuated vaccines } \\
\text { Rational vaccine design }\end{array}$ & $\begin{array}{l}\text { Malaria subunit vaccine RTS,S } \\
\text { (with AS02 adjuvent) in phase } 3 \\
\text { clinical trials in children in } \\
\text { Mozambique. }\end{array}$ \\
\hline
\end{tabular}

Improved methods of Needle-free technologies reduce vaccine delivery need for trained personnel, risk of HIV infection

Controlled release systems help overcome noncompliance Heat-stability eliminates need for refrigeration

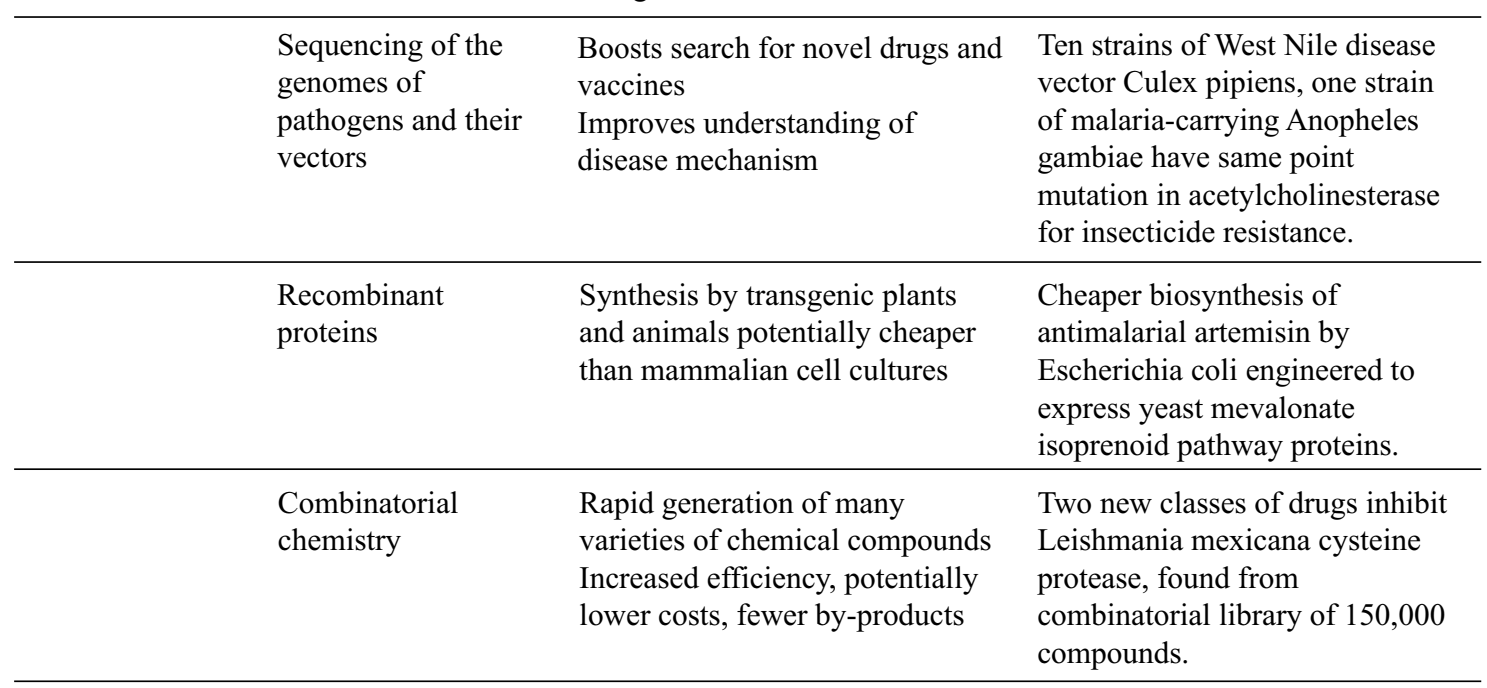




\begin{tabular}{|c|c|c|c|}
\hline $\begin{array}{l}\text { Improving } \\
\text { children's } \\
\text { nutrition }\end{array}$ & $\begin{array}{l}\text { Nutritionally } \\
\text { enhanced genetically } \\
\text { modified crops }\end{array}$ & $\begin{array}{l}\text { Many households in developing } \\
\text { countries that cannot afford a } \\
\text { diversified diet } \\
\text { Can get essential micronutrients } \\
\text { through crops whose nutritional } \\
\text { content has been genetically } \\
\text { enhanced }\end{array}$ & $\begin{array}{l}\text { Golden rice, engineered to } \\
\text { express } B \text {-carotene, further } \\
\text { development at International Rice } \\
\text { Research Institute Ferritin- } \\
\text { enriched rice. }\end{array}$ \\
\hline $\begin{array}{l}\text { Ensuring } \\
\text { environmental } \\
\text { sustainability }\end{array}$ & Bioremediation & $\begin{array}{l}\text { Harness ability of microbes and } \\
\text { plants to detect and degrade } \\
\text { environmental pollutants in low- } \\
\text { cost, sustainable manner }\end{array}$ & $\begin{array}{l}\text { NT-26 may help clear arsenic- } \\
\text { contaminated water. Transforms } \\
\text { arsenite to less soluble, less toxic } \\
\text { arsenate. }\end{array}$ \\
\hline $\begin{array}{l}\text { Promoting } \\
\text { gender equality } \\
\text { with } \\
\text { biotechnology }\end{array}$ & $\begin{array}{l}\text { Female-controlled } \\
\text { protection against } \\
\text { STIs }\end{array}$ & $\begin{array}{l}\text { Women need control over } \\
\text { technology to protect themselves } \\
\text { from STIs } \\
\text { Promotes gender equality through } \\
\text { female empowerment }\end{array}$ & $\begin{array}{l}\text { Novel mandelic acid } \\
\text { condensation polymer blocks } \\
\text { binding of HIV and Herpes } \\
\text { simplex to cells (targets gp } 120 \\
\text { and gB-2), low cytotoxicity } \\
\text { compared with existing vaginal } \\
\text { microbicides. }\end{array}$ \\
\hline
\end{tabular}

\section{Funding}

This work was funded by the Canadian Program on Genomics and Global Health (CPGGH). CPGGH receives most of its funding from Genome Canada and the Ontario Research and Development Challenge Fund. A full list of funders is available at www.geneticsethics.net. ASD is supported by the McLaughlin Centre for Molecular Medicine at the University of Toronto and PAS is supported by a Distinguished Investigator award from the Canadian Institutes of Health Research and Toronto.

\section{Acknowledgments}

We thank Tara Acharya and Halla Thorsteinsdottir for their contributions to some of the projects that have been highlighted here.

\section{References}

1. Singer PA, Daar AS. Harnessing genomics and biotechnology to improve global health equity. Science 2001;294:87-9.

2. World Health Organization. Genomics and world health: report of the Advisory Committee on Health Research. Geneva: World Health Organization; 2002.

3. Daar AS, Thorsteinsdottir H, Martin DK, Smith AC, Nast S, Singer PA. Top ten biotechnologies for improving health in developing countries. Nature Genetics 2002;32:229-32.

4. Bojang KA, et al. Efficacy of RTS,S/AS02 malaria vaccine against Plasmodium falciparum infection in semi-immune adult men in The Gambia: a randomized trial. The Lancet 2001;358:1927-34.

5. Santini J, et al. A new chemolithoautotrophic arsenite-oxidizing bacterium isolated from a gold mine: Phylogenetic, physiological, and preliminary biochemical studies. Applied and environmental microbiology 2000;66:92-7. (Cited by: Daar AS, Thorsteinsdottir H, Martin DK, Smith AC, Nast S, 
Singer PA. Top ten biotechnologies for improving health in developing countries. Nature Genetics 2002;32:229-32.)

6. Pizza M, et al. Identification of vaccine candidates against serogroup B meningococcus by wholegenome sequencing. Science 2000;287:1816-20.

7. Population Council. Carraguard: A microbicide in development. New York: Population Council; 2004.

8. Ye X, et al. Engineering the provitamin A (b-carotene) biosynthetic pathway (carotenoid-free) rice endosperm. Science 2000;287:303-5.

9. Varmus H, Klausner R, Zerhouni E, Acharya T, Daar AS, Singer PA. Grand Challenges in Global Health. Science 2003;302:398-9.

10. Acharya T, Daar AS, Singer PA. Biotechnology and the UN's Millennium Development Goals. Nature Biotechnology 2003;21:1434-6.

11. Thorsteinsdottir H, Daar AS, Smith RD, Singer PA. Genomics-a global public good? The Lancet 2003;361:891-2.

12. Pearson S, Jia H, Kandachi K. China approves first gene therapy. Nature Biotechnology 2004;22:3-4.

13. Sanchez GJ. Developing a Platform for Genomic Medicine in Mexico. Science 2003;300:295-6. 